\title{
Extract of oats as a modulator of fatty acid composition of geese tissues in the conditions of physiological stress
}

Olena Danchenko ${ }^{\star, i D, ~ 1,2, ~}$

Lubov Zdorovtseva ${ }^{2}$,

Oleg Vishchur ${ }^{3}$,

Oleksandr Koshelev ${ }^{1}$,

Tatiana Halko',

Mykola Danchenko²,

Yulia Nikolayeva ${ }^{1}$,

Daniel Mayboroda ${ }^{2}$

${ }^{1}$ Bogdan Khmelnitskiy Melitopol

State Pedagogical University,

20 Getmanska St.,

Melitopol 72312, Ukraine

${ }^{2}$ Dmytro Motornyi Tavria

State Agrotechnological University,

18 B. Khmelnytsky Ave.,

Melitopol 72310, Ukraine

${ }^{3}$ Institute of Animal Biology of NAAS,

38 V. Stusa St., Lviv 79034, Ukraine
Feeding natural antioxidant supplements to animals and birds has multiple advantages over traditional synthetic vitamins of the antioxidant group. This study investigated the effect of the Avena sativa extract on the antioxidant status and fatty acid composition of liver tissues, the brain, and skeletal muscles of geese, live weight dynamics, and pterylographic parameters during physiological stress of formation of contour and juvenile feathers. It is confirmed that adding oat extract to the geese diet during physiological stress increases tissue antioxidant activity. It was established that during the formation of contour feathers (day 28), the voltage of the antioxidant system is significantly weakened by the action of the extract due to selective inhibition of the synthesis of unsaturated fatty acids, in particular oleic. The synthesis of palmitic and stearic acids is activated. The oat extract caused the most remarkable changes in liver tissues. The subsequent period of formation of juvenile feathers ( 49 days) is characterized by equalization of the composition of fatty acids in the control and experimental groups. At the end of the experiment, the mass of the geese of the experimental group increased by $17.9 \%$ and their pterylographic parameters improved.

Keywords: geese, antioxidant activity, oat extract, fatty acid composition, feathers

\footnotetext{
* Corresponding author. Email: nndea@ukr.net

iD https://orcid.org/0000-0001-5049-3446
} 


\section{INTRODUCTION}

The use of antioxidants in feeding birds helps to eliminate the harmful effects of negative factors of different aetiologies. The use of natural antioxidant additives in feeding birds has a number of advantages over traditional synthetic additives. In addition to the known compounds of the phenolic nature of bioflavonoids, more complex phenols - avenantramids, which are charplex phenols - avenantramids, which are chartivity than other natural antioxidants (Nie et al., tivity than other natural antioxidants (Nie et al.,
2006; Viskupičová et al., 2008; Skoglund, 2008; Meydani, 2009; Antonini et al., 2017; Chen et al., 2018) have been found in the grass of oats. Fatty acids are the main components of cell membranes; they play a key role in energy homeostasis and participate in the antioxidant tissue response (Danchenko et al., 2012). It is also known that fatty acid synthase (FAS) is a multienzymic complex that catalyses the synthesis of de novo fatty acids. Inhibition of these enzymes, in turn, may be subject to inhibition by the action of natural flavonoids (Brand et al., 2010; Vauzour et al., 2015; Zhang et al., 2016), which may lead to a decrease in the unsaturation of lipids and, consequently, increase tissue resistance to the action of free radicals.

The purpose of this study was to find out the effect of Avena sativa extract on the antioxidant status and fatty acid composition of the liver tissues of the liver, the brain, and skeletal muscles of geese, the dynamics of their live weight, and the pterylographic parameters during the physiological stress of the formation of contour and juvenile feathers in these birds.

\section{MATERIALS AND METHODS}

The research was conducted on Legarth geese. On the principle of analogues, two groups of 14-day-old geese (control and experimental), 26 birds in each, were formed. Throughout the experiment, the birds of the control group were kept on a standard diet blanced on exwere kept on a standard diet balanced on exchange energy, protein, and vitamins in accordance with the recommendations (Ryabokon 2005). The geese of the experimental group drank oat extract from day 14 to day 49. For the extraction of bioflavonoids of the Avena sativa the boveground part in the earing and flowering phase was used. The removal of flavonoids from the raw material was carried out with the help of water (the ratio of the raw material and extractant was 1:10, the extraction time in the boiling water bath was $60 \mathrm{~min}$ ) followed by the extract diluted three times.

The slaughter of the geese and the selection of the biological material for biochemical studies were carried out in compliance with the standards of the Convention of the Council of Europe on the protection of animals used in scientific research. Research material was the tissues of the brain, liver, and the muscle tissue of geese. Determination of antioxidant activity and fity acid composition of thesetissues was carried out at physiologically grounded terms: day 14 - completion of postnatal adaptation, day 28 - formation of contour feathers, day 49 - formation of juvenile feathers, and day 56 - presence of the formed feathers and stabilization of the prooxidant-antioxidant equilibrium (Khvostyk, 2013).

Intensity of peroxide oxidation processes was evaluated by the content of their end products (TBARC) in tissue homogenates and by the initiation of $\mathrm{Fe}^{2+}$ (TBARCi) lipid peroxidation (Ionov et al., 2011). As an integral indicator of the state of the antioxidant protection system (AOP), the coefficient of antioxidant activity $\left(\mathrm{C}_{\mathrm{AOA}}\right)$ was used. It was calculated as the ratio of TBARC to TBARCi, since tissue homogenates contain not only the peroxidation substrate, but also components of the AOP system that can inhibit lipid peroxidation (Danchenko et al., 2012).

The content of the fatty acids was determined by gas-liquid chromatography; lipid extracts for analysis was carried out according to E. G. Bligh and W. J. Dyer (1959) with the recommendations of F. B. Palmer (1971) In addition to the total content of unsaturated falty acids (UTA) ( $\Sigma$, $\%)$, the total equivalent concentration of fatty acids (FA) was calculated for the multiple bonds (unsaturation, $\Sigma \mathrm{N}, \mathrm{mMol} / 100 \mathrm{~g}$ ) (Danchenko et al., 2003).
In parallel, the dynamics of the live weight $48.0 \%$, the brain $57.6 \%$, and in skeletal muscles of geese and their pterylographic parameters by $29.4 \%$. At the same time, under the influence were monitored. The statistical processing of of the oat extract, the reduction of antioxidant the results was carried out with Microsoft Of- activity significantly decreased in the tissues of fice Excel 2013 and SPSS v.13 packages with 28-day-old geese of the experimental group. the Student t-criterion (Landau, Everitt, 2003). Thus, the liver $\mathrm{C}_{\mathrm{AOA}}$ of this group decreased by

\section{RESULTS AND DISCUSSION}

Eggshell hatching of the embryos at the end of the embryonic period causes a transition from hypoxia to hyperoxia of atmospheric respiration. This is the genetically-programmed oxidative stress (OS). The ability of the chicks to form an adaptive response to OS at this age is determined by the initial quality of the hatching eggs and the conditions of their incubation. A number of studies have shown that when the diet is balanced and technological conditions are maintained, the postnatal adaptation of the geese is completed by the age of two weeks (Sheremet, Melnik, 2014). Formation of the adaptive response to the conditions of postnatal existence is accompanied by an increase in the antioxidant status of their organism (Pashchenko, 2013). The results of the experiment confirmed a sufficiently high level of $\mathrm{C}_{\mathrm{AOA}}$ in all investigated tissues of 14-day-old geese (Table 1).

From day 14 to day 28 , the contour feathers are formed, and in the birds of the control group, the decrease in $\mathrm{C}_{\mathrm{AOA}}$ was observed in all investigated tissues, namely: in the liver by only $37.3 \%$ compared with the 14-day limit the brain $\mathrm{C}_{\mathrm{AO}}$ by $15.8 \%$, and skeletal muscles by $25.0 \%$.

It is known that one of the mechanisms for increasing the antioxidant status of tissues of a functioning organism during physiological stress may be the reduction of the content of the main substrate of peroxide oxidation of lipids of unsaturated fatty acids and, accordingly, of the ability of lipid of biomembranes to oxidamage. The determination of the changes in the fatty acid composition during the formation of contour and juvenile feathers will allow assessing their role in increasing the adaptive potential of geese at this stage of development. A comparative analysis of fatty acid composition (FAC) of the investigated tissues of the geese of the control group on day 14 and day 28 suggests the presence of certain changes in the composition of fatty acids. However, these differences are insignificant compared with the difference in FAC of 28-day-old geese of the control and experimental groups. First of all, attention is paid to the sharp drop in content of UFA under the influence of the extract. Thus, in the liver tissues of the ex-
perimental group, this indicator decreased by
Table 1. Coefficient of antioxidant activity in tissues and live weight of geese $(M \pm m, n=6)$

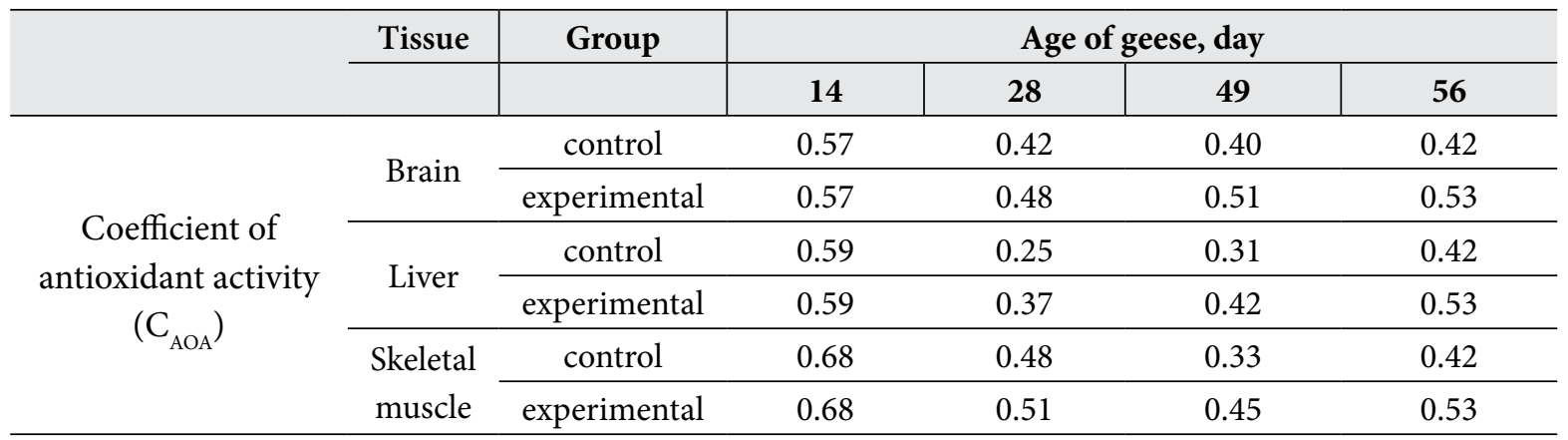

\begin{tabular}{lccccc}
\multirow{3}{*}{ Weight of geese, $k g$} & control & $0.61 \pm 0.13$ & $2.05 \pm 0.11$ & $2.68 \pm 0.14$ & $2.95 \pm 0.09$ \\
\cline { 2 - 6 } & experimental & $0.61 \pm 0.13$ & $2.12 \pm 0.08$ & $2.91 \pm 0.10$ & $3.48 \pm 0.13^{*}$
\end{tabular} Note: difference is probable relative to the control group: ${ }^{*}-p \leq 0.05$. 
18.3 times (Table 2), in the brain by 2.46 times selective metabolism of UFA aimed at reducing (Table 3), and in the skeletal muscle by 3.62 the content of polyunsaturated fatty acids (PUtimes (Table 4) compared with the control FAs). Amo group.

The largest decrease of unsaturation of the FA was in the liver (10.5 times) and the smallest in the brain (1.85 times). Consequently, an increase in antioxidant activity occurs both at the expense the sharp drop in the content of oleic acid under the sharp drop in the content of oleic acid under the influence of the extract: in the liver of the exthe brain 43.6, and in the skeletal muscle - 86.5 of the reduction of the total content of UFA and times smaller than the corresponding control

Table 2. The content $(\omega, \%)$ and total unsaturation $(\Sigma \mathrm{N}, \mathrm{mMol} / \mathbf{1 0 0} \mathrm{g})$ of fatty acids in the liver of the geese of the control $(\mathrm{C})$ and experimental $(\mathrm{E})$ groups $(\mathrm{M} \pm m, n=5)$

\begin{tabular}{c|c|c|c|c|c|c|c}
\hline \multirow{2}{*}{ Acid } & \multicolumn{7}{|c}{ Age of geese, days } \\
\cline { 2 - 8 } & $\mathbf{1 4}$ & \multicolumn{2}{|c|}{$\mathbf{2 8}$} & \multicolumn{2}{|c|}{49} & \multicolumn{2}{|c}{56} \\
\cline { 2 - 8 } & $\mathrm{C}$ & $\mathrm{C}$ & $\mathrm{E}$ & $\mathrm{C}$ & $\mathrm{E}$ & $\mathrm{C}$ & $\mathrm{E}$ \\
\hline$(16: 0)$ & $28.76 \pm 1.23$ & $27.29 \pm 0.93$ & $50.83 \pm 2.14^{* *}$ & $27.11 \pm 1.09$ & $25.80 \pm 1.17$ & $24.21 \pm 1.07$ & $19.07 \pm 0.67^{*}$ \\
\hline$(18: 0)$ & $19.87 \pm 0.94$ & $25.02 \pm 0.74$ & $42.27 \pm 1.32^{* *}$ & $22.51 \pm 1.73$ & $23.21 \pm 0.95$ & $22.93 \pm 0.99$ & $25.64 \pm 1.12$ \\
\hline$(18: 1)$ & $34.45 \pm 1.25$ & $29.05 \pm 0.82$ & $0.18 \pm 0.01^{* *}$ & $27.00 \pm 0.98$ & $25.73 \pm 1.03$ & $23.02 \pm 1.14$ & $22.96 \pm 0.98$ \\
\hline$(18: 2)$ & $5.44 \pm 0.37$ & $7.70 \pm 0.21$ & $0.08 \pm 0.00^{* *}$ & $8.69 \pm 0.27$ & $7.91 \pm 0.24$ & $8.88 \pm 0.31$ & $8.48 \pm 0.39$ \\
\hline$(18: 3)$ & $0.04 \pm 0.00$ & $0.04 \pm 0.00$ & $0.04 \pm 0.00$ & $0.08 \pm 0.00$ & $0.07 \pm 0.00$ & $0.29 \pm 0.09$ & $0.13 \pm 0.00^{* *}$ \\
\hline$(20: 4)$ & $4.19 \pm 0.28$ & $5.43 \pm 0.20$ & $1.42 \pm 0.03^{* *}$ & $7.66 \pm 0.28$ & $9.77 \pm 0.29^{*}$ & $12.45 \pm 0.42$ & $16.66 \pm 0.58^{*}$ \\
\hline$(22: 4)$ & $0.15 \pm 0.00$ & $0.32 \pm 0.01$ & - & $0.55 \pm 0.02$ & $0.86 \pm 0.03^{* *}$ & $0.55 \pm 0.02$ & $0.71 \pm 0.03^{* *}$ \\
\hline$(22: 6)$ & $0.26 \pm 0.01$ & $0.15 \pm 0.00$ & - & $0.51 \pm 0.01$ & $1.04 \pm 0.04^{* *}$ & $1.12 \pm 0.03$ & $1.48 \pm 0.06^{*}$ \\
\hline$\Sigma \omega$ UFA & 47.8 & 45.88 & 2.51 & 47.47 & 48.17 & 49.70 & 52.56 \\
\hline$\Sigma \mathrm{N}$ & 239.03 & 250.59 & 23.80 & 290.96 & 321.94 & 361.09 & 405.30 \\
\hline
\end{tabular}

Note: difference is probable relative to the control group: ${ }^{*}-p \leq 0.05 ;{ }^{* *}-p \leq 0.01$.

Table 3. The content $(\omega, \%)$ and total unsaturation $(\mathbf{~ N}, \mathbf{m M o l} / \mathbf{1 0 0} \mathrm{g})$ of fatty acids in the brain of the geese of the control (C) and experimental (E) groups $(\mathrm{M} \pm m, n=5)$

\begin{tabular}{c|c|c|c|c|c|c|c}
\hline \multirow{2}{*}{ Acid } & \multicolumn{7}{|c|}{ Age of geese, days } \\
\cline { 2 - 8 } & $\mathbf{1 4}$ & \multicolumn{2}{|c|}{$\mathbf{2 8}$} & \multicolumn{2}{|c}{49} & \multicolumn{2}{|c}{$\mathbf{5 6}$} \\
\cline { 2 - 8 } & $\mathrm{C}$ & $\mathrm{C}$ & $\mathrm{E}$ & $\mathrm{C}$ & $\mathrm{E}$ & $\mathrm{C}$ & $\mathrm{E}$ \\
\hline$(16: 0)$ & $29.39 \pm 1.35$ & $32.67 \pm 1.17$ & $44.04 \pm 1.57^{* *}$ & $25.88 \pm 1.17$ & $25.04 \pm 1.03$ & $25.66 \pm 1.12$ & $21.95 \pm 0.96$ \\
\hline$(18: 0)$ & $25.17 \pm 1.08$ & $25.24 \pm 1.04$ & $38.17 \pm 1.05^{* *}$ & $22.06 \pm 0.93$ & $21.82 \pm 0.97$ & $22.51 \pm 0.93$ & $21.21 \pm 1.08$ \\
\hline$(18: 1)$ & $22.02 \pm 0.89$ & $18.03 \pm 0.72$ & $0.42 \pm 0.01^{* *}$ & $21.95 \pm 1.02$ & $21.73 \pm 0.83$ & $21.85 \pm 1.05$ & $21.23 \pm 0.83$ \\
\hline$(18: 2)$ & $0.67 \pm 0.02$ & $0.95 \pm 0.03$ & $1.48 \pm 0.03^{*}$ & $1.46 \pm 0.04$ & $1.15 \pm 0.04^{*}$ & $0.70 \pm 0.02$ & $1.04 \pm 0.03^{*}$ \\
\hline$(18: 3)$ & - & $0.08 \pm 0.00$ & $0.37 \pm 0.02^{* *}$ & - & - & - & - \\
\hline$(20: 4)$ & $6.87 \pm 0.31$ & $6.85 \pm 0.16$ & $8.46 \pm 0.27^{*}$ & $7.45 \pm 0.27$ & $6.30 \pm 0.19^{*}$ & $6.98 \pm 0.24$ & $9.26 \pm 0.27^{*}$ \\
\hline$(22: 3)$ & $0.75 \pm 0.28$ & $0.66 \pm 0.02$ & $0.06 \pm 0.00^{* *}$ & $0.93 \pm 0.03$ & $1.05 \pm 0.06$ & $0.88 \pm 0.03$ & $1.07 \pm 0.03$ \\
\hline$(22: 4)$ & $1.66 \pm 0.05$ & $2.11 \pm 0.08$ & $0.17 \pm 0.01^{* *}$ & $3.31 \pm 0.13$ & $3.11 \pm 0.05$ & $364 \pm 0.11$ & $5.63 \pm 0.18^{* *}$ \\
\hline$(22: 6)$ & $3.99 \pm 0.09$ & $3.68 \pm 0.12$ & - & $6.56 \pm 0.22$ & $7.11 \pm 0.28$ & $7.65 \pm 0.29$ & $7.15 \pm 0.2$ \\
\hline$\sum \omega$ UFA & 39.68 & 36.66 & 14.93 & 45.77 & 45.74 & 45.83 & 49.68 \\
\hline$\Sigma \mathrm{N}$ & 287.45 & 275.77 & 148.89 & 368.10 & 364.39 & 379.16 & 426.95 \\
\hline
\end{tabular}

Note: difference is probable relative to the control group: ${ }^{*}-p \leq 0.05 ;^{* *}-p \leq 0.01$.

Table 4 . The content $(\omega, \%)$ and total unsaturation $(\Sigma \mathrm{N}, \mathbf{m M o l} / \mathbf{1 0 0} \mathrm{g})$ of fatty acids in the skeletal muscle of the geese of the control (C) and experimental (E) groups $(\mathrm{M} \pm m, n=5)$

\begin{tabular}{c|c|c|c|c|c|cc}
\hline \multirow{2}{*}{ Acid } & \multicolumn{7}{|c}{ Age of geese, days } \\
\cline { 2 - 8 } & $\mathbf{1 4}$ & \multicolumn{2}{|c|}{$\mathbf{2 8}$} & \multicolumn{2}{|c|}{$\mathbf{9 9}$} & \multicolumn{2}{|c}{$\mathbf{5 6}$} \\
\cline { 2 - 8 } & $\mathbf{C}$ & $\mathrm{C}$ & $\mathrm{E}$ & $\mathrm{C}$ & $\mathrm{E}$ & $\mathrm{C}$ & $\mathrm{E}$ \\
\hline$(16: 0)$ & $29.13 \pm 1.32$ & $21.09 \pm 1.03$ & $38.64 \pm 1.17^{* *}$ & $24.71 \pm 1.07$ & $22.93 \pm 1.03$ & $20.94 \pm 1.07$ & $21.70 \pm 1.02$ \\
\hline$(18: 0)$ & $18.13 \pm 0.79$ & $21.94 \pm 0.98$ & $43.28 \pm 1.38^{* *} 14.18 \pm 0.52$ & $15.67 \pm 0.48$ & $16.39 \pm 0.35$ & $14.69 \pm 038$ \\
\hline$(18: 1)$ & $30.27 \pm 1.18$ & $25.94 \pm 1.04$ & $0.30 \pm 0.01^{* *}$ & $38.24 \pm 1.14$ & $37.27 \pm 1.15$ & $3371 \pm 1.52$ & $39.53 \pm 1.33^{*}$ \\
\hline$(18: 2)$ & $12.35 \pm 0.62$ & $13.91 \pm 0.52$ & $3.30 \pm 0.12^{* *}$ & $11.11 \pm 0.37$ & $12.78 \pm 0.36$ & $11.94 \pm 0.47$ & $11.30 \pm 0.41$ \\
\hline$(18: 3)$ & $0.15 \pm 0.00$ & $0.09 \pm 0.00$ & $0.15 \pm 0.00^{*}$ & $0.17 \pm 0.01$ & $0.24 \pm 0.01^{*}$ & $0.19 \pm 0.01$ & $0.26 \pm 0.01^{*}$ \\
\hline$(20: 4)$ & $4.06 \pm 0.14$ & $8.61 \pm 0.32$ & $7.39 \pm 0.28$ & $5.56 \pm 0.19$ & $4.70 \pm 0.21$ & $9.60 \pm 0.37$ & $5.86 \pm 0.17^{*}$ \\
\hline$(22: 3)$ & $0.09 \pm 0.00$ & $0.19 \pm 0.01$ & $0.21 \pm 0.00$ & $0.14 \pm 0.00$ & $0.17 \pm 0.00$ & $0.15 \pm 0.00$ & $0.09 \pm 0.00^{*}$ \\
\hline$(22: 4)$ & - & $0.20 \pm 0.00$ & - & $0.29 \pm 0.01$ & $0.29 \pm 0.01$ & $0.32 \pm 0,01$ & $0.11 \pm 0.01^{*}$ \\
\hline$(22: 6)$ & $0.21 \pm 0.01$ & $0.15 \pm 0.01$ & - & $0.21 \pm 0.00$ & $0.49 \pm 0.02^{* *}$ & $0.43 \pm 0.02$ & $0.29 \pm 0.00^{* *}$ \\
\hline$\sum \omega$ UFA & 50.61 & 52.83 & 14.61 & 59.12 & 58.61 & 59.20 & 61.39 \\
\hline$\sum \mathrm{N}$ & 273.21 & 326.44 & 142.82 & 314.54 & 312.67 & 356.74 & 324.02 \\
\hline
\end{tabular}

Note: difference is probable relative to the control group: ${ }^{*}-p \leq 0.05 ; * *-p \leq 0.01$

group indicator. At the same time, a significant increase in saturated palmitic and stearic acids (the smallest - in the brain, and most - in CM) is established. Attention is drawn to the high tissue specificity of changes in the content of essential linoleic acid (LA). Thus, under the influence of the extract in the liver tissues, the content of LA was reduced by 96.3 times, in skeletal muscles - by 4.2 times, and in the brain even increased by $55.8 \%$. The content of the second essential linolenic acid in the liver remained at the level of the corresponding indicator of the control group, in the skeletal muscle it increased by $66.7 \%$, and in the brain by 4.6 times. The content of essential arachidonic acid (AA) significantly decreased in the liver and the skeletal muscle, but in the brain it increased by $23.5 \%$ Under the influence of the extract, most unsaturated $\omega-3$ docosahexaenoic acid disappeared altogether in all tissues.

Consequently, under the influence of the oat extract, the physiological tension in the organism of geese associated with the formation of contour feathers is significantly weakened by the inclusion of regultory mechans the inclysion selectively inhibit the ko et al., 2003). In the first place, this concerns $\Delta-9$ desaturase, which is involved in the synthe- sis of oleic acid. At the same time, elongases, which participate in the synthesis of palmitic and stearic acids, are activated. A comparative analysis of FAC changes in the investigated tissues suggests that the most dramatic changes under the influence of the oat extract occurred in liver tissues. By the level of UFA falling, the investigated fabrics can be placed in a row: the liver - the skeletal muscles - the brain.

Subsequent changes in FAC, which accompany the formation of juvenile feathers in 49-day-old geese, are characterized by (1) equalization of FAC of control and experimental groups, (2) an increase in the content of $\mathrm{OA}$ and, conversely, (3) a decrease in the content of palmitic and stearic acids. The most significant differences in the tissues of 49-day-old geese are set osatetraenoic, docosahexaenoic) and skeletal muscle (docosahexaenoic)

Consequently, the antioxidant effect of the extract is also manifested in the formation of juvenile feathers. However, this influence at the stage of formation of juvenile feathers is realised through another mechanism, which is confirmed by the absence of a significant difference in FAC of 49-day-old geese of the control and experimental groups. 
The completion of feathering processes of 56-day-old geese is accompanied by the stabilization of the prooxidant-antioxidant equilibrium in the tissues. The transition to this state is characterized by a gradual increase in the total content of UFA and unsaturation of FA. In the liver, the increase of unsaturation occurs mainly due to AA and docosahexaenoic acid. In the brain, it occurs due to LA, AA, and docosatetraenoic acid.

In the skeletal muscle, a certain tendency of an increase in the total content of UFA was observed at the expense of OA and linoleic acid against the background of reduction of the content of other PUFA, and this was accompanied by a decrease in the unsaturation of FA.

Thus, the antioxidant activity of the oat extract at the earlier stages of the development of the bird organism is manifested by selective modulation of the synthesis of fatty acids.

The control of the weight dynamics of the geese during the experiment indicates a certain tendency of weight increase in the geese of the experimental group compared with the control one (Table 1). However, a significant weight trol one (Table 1). However, a significant weight
increase in the geese of the experimental group compared to the control group (17.9\%) was observed only at the end of the experiment, at 56 days of age, and this was an additional confirmation of the activation of the AOP of geese under the influence of the oat extract.

During the comparative analysis of the plumage stage in the geese of the control and experimental groups at the end of the experiment (Figure), it was found that in the control group the birds' feathers - especially the fly feathers that were in the process of formation - looked sloppy. The development of feathers was somewhat delayed (Figure), especially the primary and secondary flywheel and steering feathers compared on, the growth of feathers on the hips and the sides of the trunk
was delayed.

In the experimental group, the plumage, overall and on individual parts, looked healthy and fresh. The flywheel and steering feathers on the back continued to grow. On other parts, the growth and hers was complete, including feathers and feather-brush on the fifth point.

Consequently, the addition of oats to the diet of geese during the formation of feathers increased the antioxidant activity of geese tissues. Increasing the antioxidant activity in geese tissues contributes not only to a significant increase in the weight of the geese at the end of the experiment, but also to the improvement of their pterylographic parameters. Therefore, in subsequent studies it would be advisable to carry out similar studies on wild species of birds in wild game nurseries, since the process of feather formation is of fundamental importance for these birds.

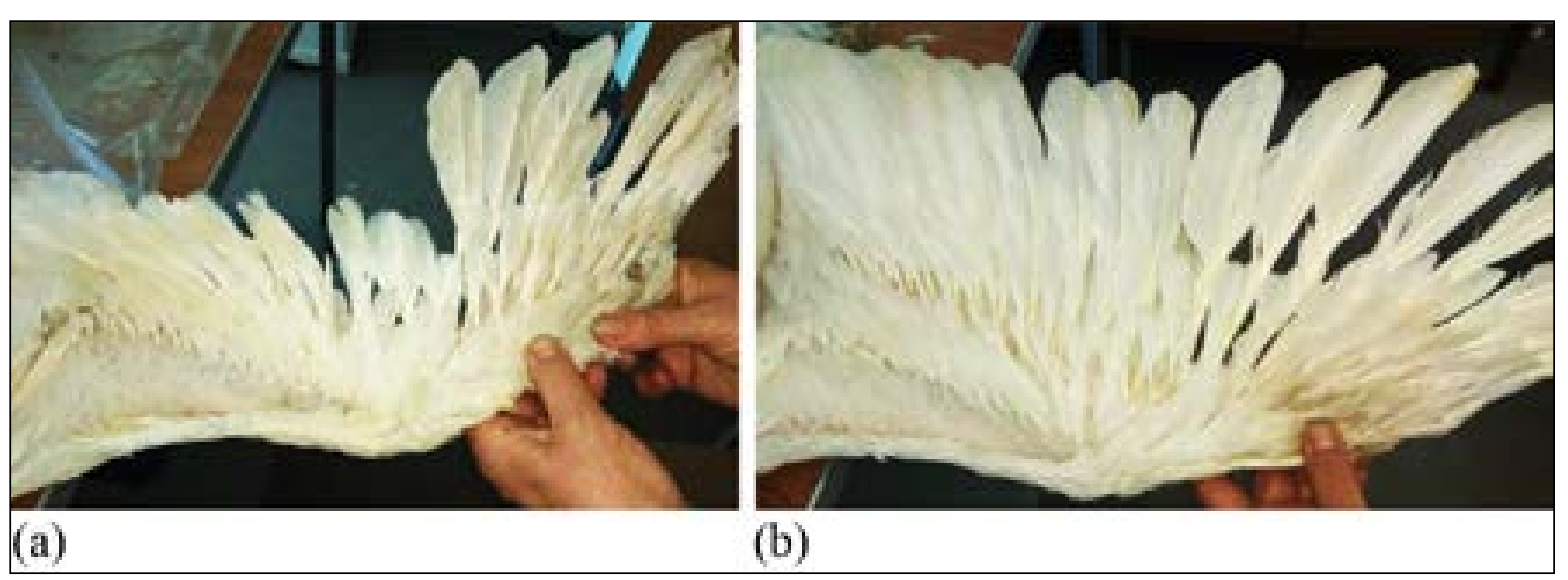

Figure. The condition of feathers of the wings of the geese of the control (a) and experimental (b) groups at 56 days of age

\section{CONCLUSIONS}

Inclusion of the oat extract in the diet of geese stabilizes the prooxidant-antioxidant balance in their tissues, and provides an increase in the antioxidant activity of these tissues during physiological stress the formation of feathers. Under the influence of the oat extract, the physiological tension associated with the formation of contour feathers is significantly weakened in of contour feathers is significantly weakened in
the geese organism by the inclusion of regulatothe geese organism by the inclusion of regulatory mechanisms that selectively inhibit the syn-
thesis of NLCs and thus weaken the ability of peroxidation. Forming juvenile feathers is characterized by a lack of significant difference FSW 49-day-old geese control and experimental groups. Increasing the antioxidant activity in geese tissues contributes not only to a significant increase in their mass at the end of the experiment, but also to the improvement of the pterylographic parameters.

Received 30 June 2019 Accepted 16 December 2019

References

1. Antonini E, Diamantini G, Ninfali P. The effect of mechanical processing on avenanth ramide and phenol levels in two organically ramide and phenol levels in two organically
grown Italian oat cultivars. J Food Sci Technol. grown Italian oat cultiv

2. Bligh EG, Dyer WI. A rapid method of total lipids extraction and purification. Can J Biochem Physiol. 1959; 37(8): 911-7.

3. Brand W, Boersma MG, Bik H, Hoek-van den Hil EF, Vervoort J, Barron D, Meinl W, Glatt H, Williamson G, van Bladeren PJ, Rietjens IMCM. Phase II metabolism of hesperetin by individual UDP-glucuronosyltransferases and sulfotransferases and rat and human tissue samples. Drug Metabol Dispos. 2010 38(4): 617-25.

4. Chen C, Wang L, Wang R, Luo X, Li Y, Li J, Chen Z. Phenolic contents, cellular antioxi- dant activity and antiproliferative capacity of different varieties of oats. Food Chem. 2018; 239: 260-7.

5. Danchenko OO, Kalitka VV, Kolesnik DM. Ontogenetic features of changes in fatty acid composition of geese liver lipids as the main substrate of peroxidation. Ukr Biochem J. 2003; 75(3): 124-9. Ukrainian.

6. Danchenko OO, Pashhenko YuP, Danchenko NM, Zdorovceva LM. Mechanisms of support prooxidant-antioxidant balance in the liver tissues of geese in hypo- and hyperoxia. Ukr Biokhim Zh. 2012; 84(6): 109-14. Ukrainian.

7. Ionov IA, Shapovalov SO, Rudenko EV, Dolgaya MN, Akhtyrsky AV, Zozulya YuA, Komisova TE, Kostyuk IA Criteria and methods for controlling metabolism in animals and birds. Kharkov: Institute of Livestock, NAAS; 2011. $378 \mathrm{p}$.

8. Khvostyk VP. Perspective directions of goose breeding. Mod Agrarian Technol. 2013; 8: 62-9. Ukrainian.

9. Landau S, Everitt BS. A handbook of statistical analyses using SPSS. Chapman and Hall/CRC. 2003, $366 \mathrm{p}$.

10. Meydani M. Potential health benefits of avenanthramides of oats. Nutr Rev. 2009; 67(12): 731-5.

11. Nie L, Wise ML, Peterson DM, Meydani M. Avenanthramide a polyphenol from oats, inhibits vascular smooth muscle cell proliferation and enhances nitric oxide production. Atherosclerosis. 2006; 186(2): 260-6.

12. Palmer FBStC. The extraction of acidic phospholipids in organic solvent mixtures containing water. Biochim Biophys Acta. 1971; 231(1): 134-44.

3. Pashchenko YuP. Antioxidant activity of the liver and heart of geese with different $\mathrm{E}$-vitamin content. Diss., Kyiv, 2013. 22 p.

14. Ryabokon YO. Recommendations for the regulation of feeding poultry. Tags: Poultry Research Institute; 2005. 101 p. Russian. 
15. Sheremet DO, Melnik VV. Breeding geese in the farm: selection of breed and formation of parent flock. Modern poultry farming. 2014; 6: 14-5.

16. Skoglund M. Phenolic compounds in oats. Diss., Uppsala, Sveriges lantbruksuniv. Acta Universitatis agriculturae Sueciae, 2008, 52 p.

17. Vauzour D, Tejera N, O’Neill C, Booz V, Jude B, Wolf I, Rigby N, Silvan JM, Curtis P, Cassidy A, Pascual-Teresa S, Rimbach G, Minihane AM. Anthocyanins do not influence long-chain n-3 fatty acid status: studies in cells, rodents and humans. J Nutr Biochem. 2015; 26(3): 211-8.

18. Viskupičová J, Ondrejovič M, Šturdík E. Bioavailability and metabolism of flavonoids. J Food Nutr Res. 2008; 47(4): 151-62.

19. Zhang JS, Lei JP, Wei GQ, Chen H, Ma CY, Jiang HZ. Natural fatty acid synthase inhibitors as potent therapeutic agents for cancers: a review. Pharm Biol. 2016; 54(9): 1919-25.
Olena Danchenko, Lubov Zdorovtseva, Oleg Vishchur, Oleksandr Koshelev, Tatiana Halko, Mykola Danchenko, Yulia Nikolayeva, Daniel Mayboroda

\section{AVIŽŲ EKSTRAKTAS KAIP ŽĄSŲ AUDINIŲ RIEBALŲ RŪGŠČIŲ SUDĖTIES MODULIA- TORIUS FIZIOLOGINIO STRESO SĄLYGO- MIS}

\section{Santrauka}

Augintinių maitinimas natūraliais antioksidantų papildais yra kur kas pranašesnis, palyginti su tradiciniais antioksidantų grupès vitaminais. Šiame tyrime buvo tiriamas avižų ekstrakto "Avena satíva“ poveikis žąsų kepenų, smegenų ir griaučių raumenų audinių antioksidantų būklei bei riebalų rūgščių sudéčiai, gyvojo svorio dinamikai, taip pat pterilografiniams parametrams formuojantis kontūrinèms ir jauniklio plunksnoms. Tyrimas patvirtino, kad $\mathfrak{i}$ žąsų mitybą ịtrauktas avižų ekstraktas padidina audinių antioksidantinị aktyvumą fiziologinio streso metu. Nustatyta, kad formuojantis kontūrinèms plunksnoms (28-oji diena) minètas ekstraktas, selektyviai slopindamas nesočiųjų riebalų rūgščių, ypač oleino, sintezę, gerokai sumažina antioksidantų sistemos įtampą. Aktyvuojama palmitino ir stearino rūgščiu sintezè. Ryškiausius pokyčius avižų ekstraktas sukèlè kepenų audiniuose. Vèlesnis jauniklių plunksnų susidarymo laikotarpis (49 dienos) pasižymi panašia riebalų rūgščių sudetimi kontrolinejje ir eksperimentinejje grupèse. Eksperimento pabaigoje bandomosios grupés žąsų mase buvo 17,9 \% didesnè, pagerèjo pterilografiniai parametrai.

Raktažodžiai: žąsys, antioksidantinis aktyvumas, avižų ekstraktas, riebalų rūgščių sudètis, plunksnos 